\title{
The Federal Income Tax on Assignments of Oil and Gas Leases
}

\author{
John W. Beveridge*
}

THE Execution of an oil and gas lease and the assignment of an oil and gas lease are often attended with unforeseeable and unexpected tax consequences. It is the purpose of this article to attempt to state the more or less definitive rules of tax law which relate to the creation and assignment of an oil and gas lease. ${ }^{1}$

What type of income has resulted from the trade? Whose income is it? When was it realized? These are the problems that confront anyone who contemplates a purchase or sale of an oil and gas lease.

It is necessary at the outset to consider briefly the present law on capital gains and losses and its application to oil and gas leases.

I.

\section{Capital Gains and Losses}

\section{General Considerations}

In considering the capital gain and loss provisions there are always two basic questions: First, is the property sold or disposed of a capital asset as defined in the Internal Revenue Code? And, second, has there been a sale or exchange?

There is a distinction between inconie derived from a sale or disposition of the property and income derived from the operation of the property. The former constitutes a capital gain; the latter constitutes ordinary income. The production of oil and gas is not regarded

*A.B. 1926, Carleton College; LI.B. 1929, University of Minnesota; formerly Assistant United States Attorney for the Northern District of Texas.

1 Depletion problems are not considered here for the reason that they unduly obscure the other basic questions. The allowance for depletion is awarded the person who has the taxable income from the exhaustion of the property, and the deduction is a subsidiary matter,-although often substantial in amount. An analysis of the problems is not facilitated hy an attempt to decide depletion questions prior to deciding the questions discussed herein. For a general discussion of depletion of oil and gas properties see 4 Mertens, Law of Federal. Income Taxation (1942) c. 24; and (1938) 36 Mich. I. Rev. 568; (1944) 22 Tax Mag. 449. See also (1943) 21 TAX Mag. 73; (1943) 21 TAX MaG. 141; (1938) 33 ILL. L. Rev. 391 ; (1938) 16 TAX Mag. 262; (1943) 21 Tex. L. Rev. 410; (1938) 47 YAIE L. J. 806; (1938) 51 HARv. I. REv. 1424. 
as a sale of the capital investment, but is regarded as an income producing operation. If the income results from the operation of the properties, it is ordinary income and is subject to depletion. If the income results from a sale of the properties, it is a capital gain and is subject to the capital gain and loss provisions. ${ }^{2}$

\section{General Rule as to Corporations}

A long term capital gain or loss is a gain or loss from the sale or exchange of a capital asset held for more than six months. A short term capital gain or loss is a gain or loss from the sale or exchange of a capital asset held for not more than six months.

Whether in the short term or long term class, a capital gain or a capital loss of a corporation is taken into account in full.

All short term and long term gains and losses are considered together and the losses (long term or short term) are deductible only to the extent of the gains. Capital losses are not deductible from ordinary income.

Any capital losses not deductible (because of the excess of capital losses over capital gains) may be carried forward into the next succeeding five years.

Generally speaking, real estate held less than six months and used in the trade or business is not a capital asset.

However, if held more than six months and a gain results on its sale, it is a capital gain, and is subject to the $25 \%$ tax only.

\section{Oil and Gas Leases Held by an Operating Company}

The Commissioner has ruled that an oil and gas lease held by an operating company is real property used in the trade or business and is excluded from the definition of capital assets in section 117 (a) (1) of the Internal Revenue Code, and sales of oil and gas leases are subject to the provisions of section $117(j)$ of the Code. ${ }^{3}$

Gains from the sale of oil and gas leases which constitute capital gains under section 117 (j) may be reported on the installment basis under section 44 of the Code if they meet the requirements for installment sales. No distinction is to be made between leases which are undeveloped and those which are producing oil or gas.

If the leases were acquired with the intention of producing oil or gas and were sold before drilling, they would be treated the same as a producing lease. If, however, a taxpayer is a dealer in leases which are held primarily for sale to customers in the ordinary course of his

2 Provided that the lease has been held more than six months. See infra.

31944 Cum. Burz. 272, I. T. 3693. 
trade or business, they are excluded from the term "capital assets" under section 117 (a) (1) of the Code. ${ }^{4}$

Thus, wherever possible, it is advisable to hold leases six months before trading them if a gain is anticipated. If a lease is sold which has not been held for six months, the gain or loss is an ordinary gain or loss; if a gain, it is taxable at the ordinary rates; and, if a loss, it is deductible from ordinary income.

If a lease is held more than six months and the taxpayer's lease transactions during the taxable year (on leases held more than six months) result in a loss, this loss is an ordinary loss and is deductible from ordinary income.

The rule as stated above in regard to gain or loss from leases held more than six months is not strictly accurate for the transactions involving leases must be considered in connection with all transactions involving other property covered by section $117(\mathrm{j})$. A more accurate statement of the rule is as follows:

If the gains from sales or exchanges of property used in the trade or business held for more than six months exceed the losses from such sales and exchanges, such gains and losses are treated under section $117(j)$ as gains and losses from sales or exchanges of capital assets held for more than six months. If such gains do not exceed such losses, such gains and losses shall not be considered as gains and losses from sales or exchanges of capital assets.

It must be borne in mind that trades in oil and gas leases must be grouped together with the other types of trades specified in section $117(\mathrm{j})$, and if the gains from all of these transactions in the taxable year exceed the losses, then all such gains and losses are treated as long term capital gains and losses. If the losses exceed the gains, then none of the gains and losses are treated as gains and losses from the sale or exchange of capital assets,- -they are all treated as ordinary gains and losses. ${ }^{5}$

4 Greene v. Commissioner (C.C.A. 5th, 1944) 141 F. (2d) 645, cert. den. (1944) 323 U.S. 717.

5 The Regulations give this example:

(1) Gain on sale of machinery, used in the business and subject to an allowance for depreciation, held for more than 6 months.... $\$ 4,000$

(2) Gain reported in 1942 (under section 44) on installment sale in 1941 of factory premises used in the business (including business and land, each held for more than 6 months. 6,000

(3) Gain reported in 1942 (under section 44) on installment sale in 1942 of land held for more than 6 months, used in the business as a storage lot for trucks. 2,000 
If the taxpayer anticipates losses from trades in leases, he should dispose of them within six months; they are not capital assets and

(4) Gain on proceeds from requisition by Government of boat, held for more than 6 months, used in the business and subject to an allowance for depreciation.

(5) Loss upon the destruction by fire of warehouse, held for more than 6 months and used in the business (excess of adjusted basis of warehouse over compensation by insurance, etc.

(6) Loss upon theft of unregistered bearer bonds, held for more than 6 months

(7) Loss in storm of pleasure yacht, purchased in 1940 for $\$ 1,800$ and having a fair market value of $\$ 1,000$ at the time of the storm

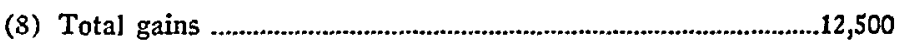

(9) Total losses

(10) Excess of gains over losses. $\$ 3,500$

(10) Excess of gains over losses. $\$ 3,500$

Since the aggregate of the respective recognized gains, $\$ 12,500$, exceeds the aggregate of such losses $(\$ 9,000)$, such gains and losses are treated under section $117(\mathrm{j})$ as gains and losses from the sale and exchange of capital assets held for more tban 6 months. A corporation will take into account $100 \%$ of the gains and losses in items 1 to 7 which are treated for all purposes as gains and losses from the sale or exchange of capital assets held for more than 6 months. Items 1 to 7 in the example will cause the inclusion of $\$ 3,500$ in computing the net long term capital gain of the corporation for the purpose of the alternative tax provided by section 117 (c) (1).

If in the example there were a loss of $\$ 4,000$ from the sale under threat of condemnation of a capital assest held for more than 6 montbs, then the gains $(\$ 12,500)$ would not exceed the losses $(\$ 9,000$ plus $\$ 4,000$, or $\$ 13,000)$. Neither the loss on such sale of a capital asset nor any of the other items set forth in the above example would then be treated as gains and losses from the sale or exchange of capital assets, but all of such items would be treated as ordinary gains and losses. Since all of such items are included in full in computing net income, the net effect of such items will be the inclusion in computing net income of a loss of $\$ 500$ (the excess of $\$ 13,000$ losses over the $\$ 12,500$ gains). If the loss on the sale of the capital asset under threat of condemnation were $\$ 3,500$, the gains and losses would still be treated as ordinary gains and losses and not as capital gains and losses, since the gaims $(\$ 12,500)$ would not exceed the losses $(\$ 9,000$ plus $\$ 3,500$, or $\$ 12,500$ ).

In making this computation, the gains and losses described in section 117 ( $j$ ) are taken into account without regard to the percentage provisions of section 117 (b), that is, 100 per cent of such gains and losses is taken into account.

If it is determmed under the above computations that the gains do not exceed the losses, none of such gains and losses are treated as gains and losses from the sale or exchange of capital assets. Such gains and losses are then not subject to the percentage limitations of section $117(\mathrm{~b})$, and such losses are not subject to the limitations provided in section 117 (d).

If it is determined under the above computations that the gains exceed the losses, all of such gains and losses are treated as gains and losses from the sale or exchange of capital assets held for more than six months. All such gains and losses are then subject to the limitations of section 117 (b), (c), and (d), relating to the percentage taken into account, the alternative tax in the case of capital gains and losses, and the extent to which capital losses are allowed. 
the losses are fully deductible from ordinary income. If he holds them more than six months and has more losses than gains on leases and other properties coming under section $117(j)$, he will have the same result, that is, the losses are deductible from ordinary income.

Or in other words: If leases are sold within six months of date of acquisition and a gam results, it is an ordinary gain. If the leases are held more than six months and then disposed of, the gains and losses from such transactions must be considered together, and if the gains exceed the losses, the capital gains provisions of the law are applicable.

\section{Above Rules Applied to an Individual}

Suppose an individual has gains and losses of the kind described in section $117(\mathrm{j})$ in these amounts:

$$
\begin{array}{rr}
\text { Total gains - - - } \$ 12,500 \\
\text { Total losses - - } 9,000
\end{array}
$$

Since his gains exceed his losses, such gains and losses are treated under section $117(\mathrm{j})$ as gains and losses from the sale or exchange of capital assets held for more than six months.

Therefore, under 117 (b) he will take into account only $50 \%$ of the amounts of the various items of gain and loss. These items will be handled the same as any other long term gains and losses of an individual, and will cause the inclusion of $\$ 1750$ (50\% of the total gain) in computing the net long term capital gain for the purposes of the alternative tax provided by section 117 (c)(2). ${ }^{6}$

If it is determined that the losses exceed the gains, none of such losses or gains is treated as gain or loss from the sale of a capital asset. Such gains and losses are then not subject to the percentage limitations of section 117 (b), and such losses are not subject to the limitations provided in section 117 (d). For example, if the taxpayer during the taxable year has losses of $\$ 1,000$ on the sale of certain depreciable machinery used in his trade or business, held for more than six months, such losses exceed such gain, and such losses and gain are not treated as losses and gain from the sale or exchange of

6 The capital gains tax for an individual is computed as follows:

(a) He will first compute his tax upon his ordinary net income excluding the amount of net long term gains over net short term losses. To this tax he will then add $50 \%$ of the amount by which his net long term gains exceed his net short term losses. This in effect results in a tax of $25 \%$ on net long term capital gain.

(b) He will include in his net income his net long term capital gain (only 50\%) and compute his tax at the regular normal tax rates and surtax rates.

He will pay whichever tax is lower. 
capital assets. The gain on the sale of the capital asset would, therefore, be taken into account in full, instead of to the extent of $50 \%$ as provided in section 117 (b).

\section{Capital Loss Carry-Over}

The aggregate of long term and short term capital losses may be applied against the aggregate of long term and short term capital gains.

If capital losses exceed capital gains, there is a net capital loss for the year. This is not deductible. This may be carried forward into the next five succeeding years until it is absorbed by the net capital gain.

The five-year capital loss carry-over is allowed only in carrying over losses sustained in taxable years beginning after December 31, 1941.

As stated above, if the losses on sales of oil and gas leases held more than six months exceed the gains, then such losses are ordinary losses and deductible from ordinary income, so the capital loss carryover provisions do not apply to them.

\section{Summary}

The mere fact that a lease is held for more than six months will not, in itself, make the disposition or transfer thereof a capital transaction; there must be a sale or exchange. An oil and gas lease is ordinarily not a capital asset, but if it is held for more than six months and then sold, the gain or loss may be considered a capital gain or loss, depending upon the results under $117(j)$. In each instance there must be a sale or other disposition required by the statute.

A loss sustained upon abandonment of a lease at any time as worthless is an ordinary loss, and the capital gain and loss provisions are not applicable nor are the provisions of section $117(\mathrm{j})$.

II.

\section{Income Which is Taxable to the Landowner}

It is essential to consider briefly the tax problems that confront the landowner who contemplates a sale of an interest in the minerals or the execution of an oil and gas lease.

A.

If the landowner purchased the fee simple estate, it is unlikely that the minerals were valued separately; and, if he now sells a part or all of the mineral interest, it will be necessary to allocate to the 
minerals a fair part of the price he paid for the entire fee simple estate at the time of acquisition. ${ }^{7}$

He will endeavor to establish a high basis for the mineral interest which he is transferring. His gain will be the difference between his basis for the minerals and the consideration he receives for their sale. The mineral interest is a capital asset and is subject to the limitations on sales of capital assets. If it is a long term sale, only $50 \%$ of the gain will be taken into account in computing his tax.

B.

If the landowner, owning all of the minerals, executes an oil and gas lease, he will usually receive a cash bonus and will retain a oneeighth royalty. The cash bonus is considered advance royalty and is taxable as ordinary income, and the one-eighth royalty is also taxable as ordinary income.

In Burnett v. Harmel ${ }^{8}$ the taxpayer owned Texas lands and executed an oil and gas lease on the lands. He received a cash or bonus payment of $\$ 57,000$ and a stipulated royalty. The taxable years 1924 and 1925 were involved, and the taxpayer wanted to return the cash payment as gain from the sale of a capital asset, this being taxable at a lower rate than other income under the 1924 Act. Under Texas law, an oil and gas lease is considered to create a determinable fee in the ininerals and is a present conveyance of the oil and gas in place. But even though title to the oil and gas passed from the lessor, the Court held that the bonus payment did not represent a gain from the sale of a capital asset, and was taxable as ordinary income.

"Bonus and royalties are both consideration for the lease and are income of the lessor. We cannot say that such payments by the lessee to the lessor, to be retained by him regardless of the production of any oil or gas, are any more to be taxed as capital gains than royalties which are measured by the actual production."

C.

Let us assume that the landowner has executed an oil and gas lease and has retained a one-eighth royalty; and that he has been paid a bonus and received rentals, but there has been no production. He now proposes to sell all his remaining interest in the minerals, this being the one-eighth royalty, and the reversion under the seven-eighths leasehold interest and all interest in future delay rentals. The bonus

7 Plow Realty Co. of Texas v. Commissioner (1945) 4 T.C. 600.

8 (1932) 287 U.S. 103. 
and the delay rentals which he had reserved do not decrease his basis in the minerals which he is now transferring. The sale of the entire remaining mineral interest would be the sale of a capital asset and subject to the capital gains and loss provisions.

In Klcbcrg v. Commissioner ${ }^{\circ}$ the taxpayer executed an oil and gas lease and then assigned her portion of the royalties for $\$ 149,341.50$, payable in two yearly installments. It was held that the assignment of the royalty constituted a sale, and the capital gain provisions are applicable.

However, if the landowner retained any interest in the minerals or royalty, the result would be different. In Pugh v. Commissioner ${ }^{10}$ the taxpayer owned a one-eighth royalty interest under an oil and gas lease. He transferred half of this one-eighth to Eastham for the total sum of $\$ 250,000-\$ 50,000$ of which was paid in cash and the balance of $\$ 200,000$ was to be paid out of the royalty interest conveyed to Eastham. The assignment stipulated that the assignor was to receive the entire one-eighth royalty until the unpaid balance of $\$ 200,000$ had been received by him out of the proceeds belonging to the share which he had sold to Eastham. It was stipulated that Eastham, the assignee, was not personally obligated to pay the $\$ 200,000$.

The court held that one-half the royalty belonged to Eastham immediately on the date of the assignment, and that his right in the oil was being depleted by the removal of the oil and that it was his income and taxable to him. The arrangement whereby the assignor received and kept the entire proceeds of the royalty interest to apply to the oil payment was held merely a pledge of the proceeds.

This case is apparently overruled, ${ }^{11}$ and the court would now hold that the royalty interest which was subject to the oil payment of $\$ 200,000$ was the income of the original lessor and taxable to him until the $\$ 200,000$ had been earned.

A landowner selling a mineral interest may effect a tax saving by use of an installment sale.

III.

\section{Income Which is Taxable to the Assignor}

The owner of an oil and gas lease who contemplates a sale of the lease must first give thought to several matters or he will find that most of his gain has been taken by the tax-gatherer.

? (1943) 2 T.C. 1024.

10 (C.C.A. 5th, 1931) 49 F. (2d) 76.

11 Commissioner v. Fleming (C.C.A.5th, 1936) 82 F. (2d) 324. 
A.

The first task is to make certain that there is a sale which is subject to the capital gains provisions. Although all other elements may be present, the form of the trade may destroy its status as a sale. The assignment should expressly indicate that a sale and conveyance has taken place and that the transaction is not a sublease. ${ }^{12}$ Most transactions in leases are actual sales and the distinction sometimes made between a sale and a sublease is not realistic and does not assist in arriving at a solution of the problem.

An operator who has invested several million dollars in producing properties should be able to compute his tax liability prior to closing a trade for their sale. If he sells his property for cash and retains an interest in production, it may be difficult to compute his tax. If he thinks that he has sold a capital asset and has reckoned his tax at $25 \%$ of the gain, he may find many months after he has closed the trade that the government claims he has not made a sale because of the retention of an interest in the property, and the cash received is taxable as ordinary income at a much higher rate.

B.

If the total consideration is cash, it is clear that there has been a sale, but most trades are not so simple.

In Commissioner v. Fleming ${ }^{13}$ the operator sold leases for cash and in addition retained an oil payment. The cash was regarded as the selling price and was held to be subject to the capital gains provisions; but the oil payment was held to be ordinary income.

In Palmer v. Bender ${ }^{14}$ the owner of a producing lease assigned it in consideration of a cash bonus and an additional payment of $\$ 1,000,000$ to be made out of one-half of the first oil produced and saved, plus a permanent overriding royalty of one-eighth of all the oil produced and saved. The Court held that the cash and the interests out of oil production are ordinary income.

Cullen v. Commissioner ${ }^{15}$ involved two types of trades, one sim-

12 1941-1 CUM. BULL. 214.

13 (C.C.A. 5th, 1936) 82 F. (2d) 324.

14 (1933) 287 U.S. 551. See also McLean v. Commissioner (C.C.A. 5th, 1941) 120 F. (2d) 942 , cert. den. (1941) 314 U.S. 670.

15 (C.C.A. 5th, 1941) 118 F. (2d) 651, rev'g (1940) 41 B.T.A. 1054.

In Haynes v. United States (Ct. Cl. 1943) 50 Fed. Supp. 238, the taxpayer was a stockholder in the Haynes Production Co., and, together with other stockholders of that company, sold out to Standard Oil of Louisiana for a cash payment and a promise to pay the vendors $\$ 10,000,000$ in monthly deferred payments to the value of a specified per- 
ilar to that in the Fleming case, the other similar to that in Palmerv. Bender. Where the leases were sold for cash and a stated oil payment was retained, the cash was held to be income from the sale of capital assets. Where the leases were sold for cash, and an oil payment and a permanent override were retained, the cash was held to be ordinary income.

In IVest v. Commissioner ${ }^{18}$ there was apparently a studied attempt to have a sale even though a royalty interest was retained. A deed to the fee simple was executed which of course included the minerals. The mineral interest was retained by a separate instrument. The taxpayer contended that there had been an absolute conveyance of the minerals; but the Court held that it was in effect an ordinary leasing arrangement and an allocable portion of the cash payment represented advance royalties and was not capital gain derived from a sale of the minerals.

In Badger Oil Co. v. Commissioner ${ }^{17}$ the taxpayer owned the leasehold interest in producing properties and then subsequently acquired two-thirds of the one-eighth royalty interest. The taxpayer then sold the leasehold interest for cash and secured notes which were paid in the year of the sale. The Court held that the transaction constituted a sale even though the taxpayer still retained his interest in the royalty.

The Supreme Court found that there had been a sale of the properties in Helvering v. Elbe Oil Land Development Co. ${ }^{18}$ The Elbe Oil Land Development Co. owned certain oil and gas leases, permits, contracts and equipment. It sold all of these properties to the Honolulu Consolidated Oil Co. in October, 1927. The Honolulu Co. agreed to pay the Elbe Co. $\$ 350,000$ upon the execution of the agreement and the additional sum of $\$ 400,000$ in the years 1928,1929 , and 1930 ,

centage of oil and gas produced, payments to cease and the $\$ 10,000,000$ to be regarded as paid when the property ceased to produce. The question was whether subsequent payments received constituted income or were subject to capital gain limitations. The Court of Claims, distinguishing Thomas v. Perkins (1937) 301 U.S. 655, held that the transaction was a unit and subject to the capital gains limitations, rather that income due to any retention of an interest in oil in place.

16 (C.C.A. 5th, 1945) 150 F. (2d) 723, aff'g (1944) 3 T. C. 431.

17 (C.C.A. 5th, 1941) 118 F. (2d) 791, aff'g (1940) 42 B. T. A. 521, cert. den., (1941) 314 U.S. 634.

18 (1938) 303 U.S. 372 . See also Estate of Dan A. Japhet v. Commissioner (1944) 3 T. C. 86; Quintana Petroleum Co. v. Commissioner (C.C.A.5th, 1941) 143 F. (2d) 588; Burton-Sutton Oil Company v. Commissioner (1944) 3 T. C. 1187; Kirby Petroleum Co. v. Commissioner and Commissioner v. Crawford (1946) 66 Sup. Ct. 409. 
and $\$ 450,000$ in the year 1931 . The agreement provided that after the Honolulu Co. was fully reimbursed for all its expenditures in the acquisition, development, and operation of the properties, that the Elbe Co. would be paid each month, one-third of the net profits resulting from the production and operation of the properties.

The Court held that this was a sale of all the properties including the oil and gas in place and the Elbe Co. did not retain any interest in the properties. The agreement to pay one-third of the net profits is merely the personal covenant of the Honolulu Co.

In Estate of Dan A. Japhet v. Commissioner ${ }^{19}$ the leases were acquired in April, 1918, and were transferred in February, 1919, which was less than one year from the date they were acquired. The consideration for the conveyance was $\$ 200,000$ cash and the retention of a one-fourth of the net profits. It is held that this is a sale, but the gain is taxable at $100 \%$ as the lease was held less than one year. It should be noted that the court does not find that the lease is a capital asset but merely says that, assuming it is a capital asset, the gain is still taxable in full. The court said:

"By reading the written instrument which is in evidence it will be observed that in the assignment by petitioners of their interest in the oil lease to Humble they did not reserve any oil royalty as that term is usually understood. They had a contract with Humble whereby in addition to the cash consideration which was paid to them for the assignment of their interests in the sublease they were to have a working interest of one-fourth of the net inoney profit realized by Humble from its operations upon said tracts of land, accountings to be had monthly once profits began to accrue. This, we think, was essentially the same sort of an arrangement as existed in Helvering v. Elbe Oil Land Developinent Co., 303 U.S. 372 ..."

Anderson v. Helvering ${ }^{20}$ was decided by the Supreme Court of the United States on May 20, 1940.

The Oklahoma City Company owned in 1931 certain royalty interests, fee interests and deferred oil payments in lands in Oklahoma.

During 1931 it entered into a contract with petitioner providing for the conveyance to him of these interests for the agreed sum of $\$ 160,000$ payable $\$ 50,000$ in cash and $\$ 110,000$ from one-half of the proceeds received by him which might be derived from oil and gas

10 (1944) 3 T. C. 86.

20 (1940) 310 U.S. 404. 
produced from the properties and from the sale of the fee title to any or all of the land conveyed.

The Oklahoma City Company was to have a first lien against "That one-half of all oil and gas production and fee interest from which $\$ 110,000$ is payable." Immediately upon the execution of the contract the properties were conveyed to petitioner without reservation.

The gross proceeds from the production and sale of oil from the properties during 1932 amounted to $\$ 81,000$. Petitioner upon receiving this sum distributed one-half to Oklahoma City Company pursuant to the contract. It was held that there had been a sale of all the property to the petitioner and the entire income from it is the taxable income of the petitioner.

Choate v. Commissioner ${ }^{21}$ was decided by the Supreme Court in January, 1945, and resolved a conflict between decisions of the fifth circuit and the tenth circuit. Choate and Hogan owned an oil and gas lease and drilled six producing wells on it and operated it until August, 1938. At that time they sold it to the Sylva Oil Company for a cash consideration of $\$ 110,000$ and they reserved one-eighth of all the oil and gas to be produced. The Court held this was a sale and the cash received is to be treated as a capital gain. The full cost of the wells, and the equipment, is to be deducted from the cash and the remainder taxed as capital gain.

It is to be noted that the Court treats the transaction as a sale even though a permanent override was retained by the assignors.

\section{C.}

If the sale is for cash and a stated sum out of a fraction of production, the immediate problem is to decide how much of the cash constitutes taxable gain. The assignor who receives the cash would like to take the position that he has not received any taxable income unless the cash exceeds the entire cost of the leases and wells. But the courts do not permit this. The assignor is entitled to recover first out of the cash the entire depreciated cost of any physical equipment sold by him in the trade.

If the cost of the equipment sold is $\$ 100,000$ and the cash paid

21 (1945) 324 U.S. 1, rev'g (C.C.A. 10th, 1944) 141 F. (2d) 641.

The companion case of Hogan v. Commissioner is reported in (C.C.A. 5th, 1944) 141 F. (2d) 92, cert. den. (1944) 323 U. S. 710. The Supreme Court adopted the rule used by the Fifth Circuit and rejected the rule applied by the Tenth Circuit.

221943 CuM. BuLL. 313. 
is $\$ 75,000$, the $\$ 25,000$ unrecovered cost is then allocated in this manner: If the retained oil payment is from one-fourth of seven-eighths and the interest transferred is three-fourths of seven-eighths, the value of the interests is estimated at the time of the sale and the $\$ 25,000$ unrecovered cost is allocated to the fractional interest retained and the interest sold. The $\$ 25,000$ represents cost of equipment that is still on the property, and if the value of the oil payment retained is one-fourth of the value of the interest sold, the assignor will be permitted to recover one-fourth of $\$ 25,000$ from income received on the oil payment. This amount is made part of his depletable cost of the oil payment; he cannot receive that amount on the oil payment tax free but must report the oil payment as income as soon as received subject to depletion. ${ }^{22}$

A typical problem was presented in Columbia Oil \& Gas Co. v. Commissioner. ${ }^{23}$ The sale was of eight producing oil and gas leases and all equipment thereon for $\$ 550,000$ cash and a reservation of a fraction of the oil and gas if, as, and when produced until $\$ 350,000$ additional was paid.

The allocation of the purchase price to the depreciable and depletable properties was accomplished by the following method:

The depreciated cost of the tangible well equipment was. $\$ 246,590.00$

The stipulated leasehold cost was. $133,307.78$

The stipulated value of the leases and equipment was $725,000.00$

Stipulated value of leases and equipment............................................. $\$ 725,000$

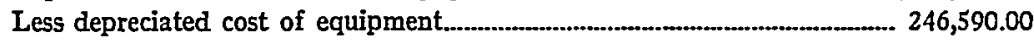

Value of lease less equipment...................................................

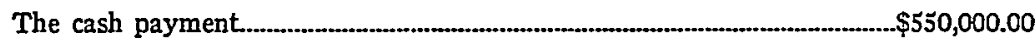

Less the depreciated cost of equipment

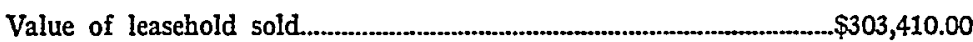

The value of the total leasehold less the equipment is................................. $\$ 478,410.00$

Less the value of the leasehold sold....................................................... 303,410.00

The difference is the value of the oil payment retained, or.......................... $\$ 175,000.00$

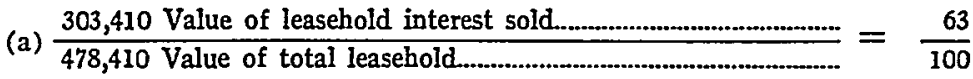

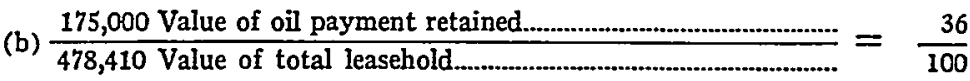

23 (C.C.A. 5th, 1941) 118 F. (2d) 459, aff'g (1940) 41 B.T.A. 38; see also Commissioner v. Roeser \& Pèndleton (C.C.A. 5th, 1941) 118 F. (2d) 462; Thomas v. Peckham Oil Company (C.C.A. 5th, 1940) 115 F. (2d) 685; Commissioner v. Lewis (C.C.A. 10th, 1942) 132 F. (2d) 709. 
The value of the leasehold retained is $63.42 \%$ of the value of the total.

The value of the oil payment is $36.58 \%$ of the value of the total.

The stipulated cost of the leasehold, $\$ 133,307.78$, is to be allocated in that proportion.

In other words, the ratio between the value of that part sold and the total fixes the amount of the leasehold cost which the seller gets back free of tax.

Cash: $\$ 550,000.00$

Leasehold: 303,410 Value of leasehold sold 478,410 Value of leasehold
less equipment. of $\$ 133,307.78=\$ 84,543.79$

Equipment Cost $246,590.00$

Expenses of Sale $\$ 331,133.79$

Total Deductions $18,552.00$

Taxable Gain $\frac{349,685.79}{\$ 200,314.21}$

This method cannot be applied so as to produce a deductible loss on the sale of the depreciable equipment. In cases in which the cash payment is less than the depreciated cost of the equipment, the excess of the cost over the cash payment represents part of the depletable cost of the interest retained in the oil and gas in place.

If there is no cash consideration, but an oil payment is retained, then the entire cost of the leasehold and equipment represents the cost of the fractional interest which the assignor has retained. ${ }^{24}$

Similar problems were involved in the Choate and Hogan cases.

Hogan v. Commissioner ${ }^{25}$ was decided by the fifth circuit in February 1944.

Choate v. Commissioner ${ }^{26}$ was decided by the tenth circuit in March $1944 .^{28 \mathrm{a}}$

Because of the importance of the issues, a statement of the decisions of the three courts is necessary.

Fred T. Hogan and W. G. Choate were partners in the oil business. The Hogan case came before the United States Circuit Court of Appeals for the Fifth Circuit. The partnership assigned certain leases and the wells thereon to the Sylva Oil Company for $\$ 110,000$ cash and reserved an overriding royalty of one-eighth of eight-eighths. The partnership treated the assignment as a sale of a capital asset; but the court held:

24 Supra note 22.

25 (C.C.A. 5th, 1944) 141 F. (2d) 92 ; cert. den. (1944) 323 U.S. 710.

26 (C.C.A. 10th, 1944) 141 F. (2d) 641.

$28 \mathrm{a}$ The Choate case went to the Supreme Court and was reversed in 324 U.S. 1. (29 Jan., 1945.) 
(a) ". . . that the partnership was not entitled to treat the assignment as a sale of a capital asset, but must look to depletion for the return of its capital.

(b) "... that title to the equipment passed from the partnership to Sylva Oil Company under the assignment, and that the partnership was entitled to deduct from the cash consideration the depreciated cost of said equipment...."

The opinion further states:

"Under the Act, depletion percentage on the bonus received and the royalty reserved is not a reduction associated with equipment cost. Equipment cost is recoverable through depreciation allowances and not 'by percentage depletion allowances', as apparently was inadvertently stated in Cullen v. Commissioner. It is only with respect to wasting assets that depletion allowances are made."

The case involving the other partner, W. G. Choate, came before the United States Circuit Court of Appeals for the Tenth Circuit. The court made the following statement of the issues:

"... In making such return the taxpayer computed the tax upon the basis of a sale by allocating the sale price of $\$ 110,000$ as $\$ 98,454.70$ to the leasehold and $\$ 11,545.30$ to equipment. The amount allocated to the leasehold was considered on the basis of a long-term capital gain and the amount allocated to equipment was accounted for through depreciation and the tax computed on the remaining difference. The Commissioner computed the tax upon the entire amount of cash consideration upon a depletion basis." ...

The court held that the original conclusions of the Commissioner were correct, and stated its reason as follows:

"... In cases where the leasehold is not specifically sold separate and distmct from the equipment thereon and the consideration for each specifically segregated the transaction must be considered in its entirety and the cost made recoverable through depletion. In the case at bar no such distinction and separation was made as the cash to be paid covered the leasehold and the equipment as a unit." ...

The Choate case came before the United States Supreme Court on writ of certiorari. The opinion of the Supreme Court is confined to the question relating to the wells and equipment. The Court upholds the Tax Court in its decision that:

"... there had been an absolute sale of the equipment, that its cost was not recoverable by depletion, and that the partners were 
entitled to an allowance for the unrecovered cost of the equipment transferred." ...

The Court further said:

"... Depletion is applicable to wasting assets-to the exhaustion of natural resources, not of property used in a business." ...

"In the second place, the Tax Court found that the parties intended a cash sale of the equipment. That question is argued here as if it were open for redetermination by us. It is not. It is the kind of issue reserved for the Tax Court under Dobson v. Coinmissioner, 320 U.S. 489, and Wilmington Trust Co. v. Helvering, 316 U.S. 164, 167,168 . Once a sale of the equipment is conceded, it is not denied that petitioner is entitled to an allowance for the unrecovered cost of the equipment transferred. Section $111(\mathrm{a}), \S \$ 13(\mathrm{a})$ and (b). No question is presented concerning the allocation of a portion of the purchase price to the equipment."

D.

If a lease is sold for cash and an oil payment is reserved, the oil payment is not considered gain until production occurs and the income is realized. ${ }^{25}$ The payments are ordinary income; and the assignor must pay an income tax on thein as they are received. He cannot take the position that the payments are not taxable until he has recovered his cost; his cost is to be recovered through depletion allowances.

If the oil payment is guaranteed, the situation is not clear. The Bureau has taken the view in recent years that a guaranteed oil payment is income to the assignor in the year in which the contract was made if the assignor is on the accrual basis. This apparently is on the theory that the transaction is a deferred payment sale. ${ }^{28}$ However, this view ignores the fact that the instrument which reserves the oil payment and in which the promise to pay is embodied is a simple contract. It is usually assignable, but seldom negotiable; and, although the absolute promise of the assignee to pay the amount may

$2 \pi$ Burnet v. Logan (1931) 283 U.S. 404 ; E. F. Simms (1933) 28 B.T.A. 988; Lee v. Commissioner (C.C.A. 5th, 1942) 126 F. (2d) 825, aff'g (1940) 42 B. T. A. 1217; Laster v. Commissioner (C.C.A. 5th, 1942) 128 F. (2d) 4, modifying (1940) 43 B.T.A. 159; Kay Kimbell (1940) 41 B.T. A. 940; Columbia Oil \& Gas Company v. Commissioner (C.C.A. 5th, 1941) 118 F. (2d) 459, af'g (1940) 41 B.T.A. 38.

28 See 2 Mertens, Law of Federal Income Taxation (1942) $\$ 11.05$ for general discussion of deferred payment sales. 
have a market value, the instrument has none of the formalities of a negotiable promissory note. ${ }^{29}$

${ }^{29}$ In Charles C. Ruprecht v. Commissioner (1929) 16 B.T. A. 919, the Board said in part:

"We do not consider, however, that the respondent's views with respect to the deferred payments are correct, for the reason that the obligation of the Standard Oil Co. to pay was not so evidenced that it could have been converted into cash, the only record thereof being in the deed of conveyance signed by the grantors. There was no contract in writing and no vendors' lien nor notes of any description which could have been discounted at the bank. In short, the obligation of the Standard Oil Co. amounted to nothing more than a mere nonmterest-bearing account receivable. The case of $\mathrm{W}$. B. Geary, 6 B.T.A. 1109, relied upon by the respondent, is clearly distinguishable and is not controlling here."

In Dearing v. Commissioner (C.C.A. 5th, 1939) 102 F. (2d) 91:

"The taxpayer, Willis R. Dearing, during the tax year 1932 was a partner in the firm of R. H. Dearing \& Company, which was doing a large business in drilling oil wells and receiving pay for its services partly in cash and partly in a right to payment of a fixed sum out of the oil and gas produced, saved and marketed froin the several wells successfully brought in. The present contest relates to the proper treatment for income tax purposes of the receipts in or from these socalled 'oil payments.' The partnership returned only the money received, having always made its returns on a cash receipts basis, and claimed that as to each successful well it should apply the receipts in money from the oil payments first to extinguish the cost of drilling the particular well and treat the excess only as a taxable gain....

". . . The Board of Tax Appeals held that although such an oil payment contract might be salable, there was too much uncertainty and contingency about it to make it a property having a readily ascertainable market value, following Edwards Drilling Co. v. Coinmissioner, 35 B.T.A. 341, affirmed 5 Cir., $95 \mathrm{~F} .2 \mathrm{~d} 719$, and that in consequence it should not be taxed as a gain until sold or until money should be received under it from the oil sales...."

The decision of the Board is affirmed.

It scems very clear that a negotiable promissory note, unless it is accepted as payment by a person on the cash basis, is not income. In Schlemmer v. United States (C.C.A. 2d, 1938) $94 \mathrm{~F}$. (2d) 77 , the suit is to recover back income taxes paid for the year 1927. Notes were executed December 31, 1927, and they were never paid. The plaintiff, the taxpayer, returned his taxes on the cash basis and erroneously paid a tax as though he had received the cash in the year the notes were executed. The Court says:

"... The plaintiff's note did not pay the company's debt, unless the parties agreed that it should. Peter v. Beverly, 10 Pet. 532, 568; Lyman v. Bank of United States, 12 How. 225, 243; The Emily Souder, 17 Wall. 666, 670; Segrist v. Crabtree, 131 U.S. 287. The defendant asserts that they had so agreed because of the tax returns; but that is not so. Those did indeed presuppose that the note was a proper entry in a cash return, but that does not show that the parties had agreed that it should be payment; they may have supposed that a note so taken always pays the debt; or that it inust be treated as cash whether it was payment or not. They were layinen, and we can tell nothing about what facts they took for true in reacling the conclusion that the note was cash. The only actual testimony was that the note was not taken as payment, but only as more permanent evidence of the debt. Indeed, it is not at all clear that it would have bcen a casl item, even if it had in fact been taken as payinent. It did not change the substance of the debt-not being endorsed or secured-and although it was more readily disposable, that single incident was scarcely enough. There must be more than difference in the mere 
The taxpayer can control this matter by an express provision in the assignment that the promise to pay, although absolute in terms, is not accepted as payment. ${ }^{30}$

form of property to justify a charge of income. Weiss v. Stearn, 265 U.S. 242. But we need not stand on that; in any case since it was not taken as payment, it could not be treated as cash; the old debt remained, the note was on more than added security. . .."

30 C. W. Titus v. Commissioner (1936) 33 B.T.A. 928, holds promises to pay out of oil were not income in year of sale to accrual basis taxpayer.

In Cook Drilling Coinpany v. Commissioner (1938) 38 B.T.A. 291, taxpayer agreed to drill wells in exchange for future payments out of oil, if, as and when produced. His right to receive such future oil payments was wholly contingent upon the happening of unpredictable future events.

In Commissioner v. Edwards Drilling Company (C.C.A. 5th, 1938) 95 F. (2d) 719, the Court said:

"Respondent, an oil well drilling company, in the year 1931, drilled for others 120 wells in the East Texas field. Each of these wells was drilled under a contract, providing for payment out of oil produced from it, of the agreed price for drilling it. As to each of the wells drilled except 3,2 contracted October 6, at $\$ 20,500$ each, and 1 October 8 , 1931 , at $\$ 50,000$, the contract price was paid out of oil produced from it within the year. From these 3, though completed in 1931, the taxpayer received only $\$ 1,821.55$ within the year. It therefore returned only that amount as income, though it deducted as ordinary and necessary business expenses, the amount of $\$ 36,113.11$ as the cost of drilling the well.

"It is of course true, as the Board points out, that under the accrual method of accounting employed by petitioner, items inust be accrued as income when the events occur to fix the amounts due and determine liability to pay. United States v. Anderson, 269 U.S. 422,46 S. Ct. 131, 70 L. Ed. 347. Generally speaking, however, the income tax law is concerned, and its administration should deal only, with realized losses, and realized gains. Lucas v. American Code Co., 280 U.S. 445, 50 S. Ct. 202, 74 L. Ed. 538, 67 A.L.R. 1010. The taxpayer therefore is under no obligation to pay a tax on income he might never receive. North American Oil Consolidated v. Burnet, 286 U.S. 417, 52 S. Ct. 613, $76 \mathrm{~L}$. Ed. 1197. A strained construction in administrative efforts to accrue income should be avoided."

In Kimbell v. Cornmissioner (1940) 41 B.T.A. 940, the Board stated:

'We think petitioners' additional contention is within the assignment of error, and should be sustained. In Edwards Drilling Co., 35 B.T.A. 341; affd., 95 Fed. (2d) 719, we said: 'The fact that the riglits had a fair market value does not of itself require that the amount thereof be accrued as taxable income.' In the instant proceedings, the respondent not only attempts to tax petitioners on what he terms as the value of the two oil payments to be received from the Richter " $B$ " and " $C$ " leases, when, as, and if produced, but also attempts to tax petitioners on the value of what they reserved in the Richter "A" lease. We think this constitutes error on the part of the respondent. Columbia Oil \& Gas Co., 41 B.T.A. 38, 46. We decide this issue, in so far as it relates to the Richter exchange, for the petitioners. There will be no taxable income from this exchange to petitioners until they have recovered from the contingent oil payments, the cost basis of the property which they gave in exchange for the contingent oil payments. Cf. Rocky Mountain Development Co., supra."

In Haynes v. United States (Ct. C1, 1943) 50 Fed. Supp. 238, the court said:

"On April 17, 1936, plaintiff sold his 567\% / shares of the stock of the Haynes Production Company to the Standard Oil Company of Louisiana. On the same day all the other stockholders in the Haynes Co. also sold their shares, to Standard, the total number 
The assignor who is on the cash basis certainly has not received income until actual payment. ${ }^{31}$ However, he too should clarify his position by appropriate terms in the assignment.

of all the shares, including plaintiff's, being 1,750. For all the shares, Standard paid in cash $\$ 3,663,141.04$, which was divided ratably among the sellers, and promised to pay $\$ 10,000,-$ 000 more, in monthly deferred payments but only to the extent of the value of threesixteenths of seven-eights of the oil and gas produced from the properties of the Haynes Production Company. When the properties had ceased to produce, the $\$ 10,000,000$ was to be regarded as having been paid.

"The stated hasis for the Government's position is that plaintiff, when he sold his stock received cash and an interest in oil and gas properties to the extent of three-sixteenths of seven-eights of their production, until they had produced plaintiff's pro rata share of the $\$ 10,000,000$; that the value of that interest, at the time plaintiff received it, was a part of the price received hy plaintiff for the sale of his capital asset; but that the income which plaintiff later received, as the product of that interest, was current income from an interest owned by plaintiff rather than payment for the stock.

"We think that the Government's analysis of the transaction is fallacious. ..."

31 In the case of Frank W. Reeves v. Commissioner, B.T.A. Memo. Op. Dkts. 109127-8, September 3, 1942, it was held that where a cash basis taxpayer received oil rights in settlement of a claim, he had no taxable income until receipt of payments thereunder. See Mertens, Section 12.39 Supplement.

George P. Douglas (1925) 1 B.T.A. 372. In this case the taxpayers were on the cash basis and claimed that the royalty they received from the iron mine in the year 1918 and reported in their 1918 return represented their portion of the profits of the mine for the period December 1, 1916, to November 30, 1917. Under the lease this anount was payahle on December 20,1917. The taxpayers contend that the royalties were constructively received on December 20,1917, and they want to amend their return and place the income in 1917. The Board of Tax Appeals denied the contention of the taxpayers.

Commissioner v. Moore (C.C.A. 10th, 1931) 48 F. (2d) 526. Sale of leases for $\$ 3,000,000$ - of this aunount $\$ 500,000$ was to be paid in cash and $20 \%$ of oil runs retained until $\$ 2,500,000$ paid with a guaranty of $\$ 500,000$ per year. Held: Taxpayer is on the cash basis and cannot account for all the consideration in the year the contract was signed.

Rocky Mountain Development Company (1938) 38 B.T.A. 1303. Held that contingent oil payments are not equivalent of cash. They held no definite fair market value and are not income in the year the trade was made. Taxpayer is entitled to recover the cost of the oil payment contracts before being chargeable with any taxable gain tbereon. See Burnet v. Logan and Commissioner v. Speyer (C.C.A. 2d, 1935) 77 F. (2d) 824.

Farrell v. Commissioner (C.C.A. 5th, 1943) 134 F. (2d) 193. In this case certain lease interests were sold in 1931 and a portion of the purchase price was payable from the first one-fourth of the working interest. The parties that owned the oil payment were divorced and payments were not made in 1933, 1934, or 1935. The divorce suit was terminated and the final decree was entered in 1936 and the plaintiff received $\$ 402,000$ which represented the oil run in 1933, 1934, and 1935. It was held that it was taxable in the year 1936.

"In each of the years involved, the taxpayer made his tax returns on the cash basis. Since the decision in North American Oil Consolidated Co. v. Burnet, 286 U.S. 417,52 S. Ct. $613,76 \mathrm{~L}$. Ed. 1197, it has been settled that income is taxable when it has been actually or constructively received, and that no tax is due with respect to income that bas not heen and may never be received. Yount-Lee was enjomed from making any oil payments to the taxpayer from July 5, 1933, until June 8, 1934, and continuously there- 
It should be borne in mind that such transactions can be handled as installment sales by complying with the requirements of section 44 of the Internal Revenue Code. ${ }^{32}$

A permanent overriding royalty is not income until it is accrued or received, and we know of no instance in which a contrary position has been taken.

IV.

INCOME WHICH IS TAXABLE TO THE ASSIGNEE

The form of the assignment is of importance to the assignee also. The tax problems should not distort the form of the trade and the demands of good business judgment. He should be certain that he acquired title to the entire interest he is purchasing, and he should not give his personal covenant to pay an oil payment if he is not certain that the property will earn it.

The assignee is concerned primarily with determining how well the interest he receives will produce income and how much of that income will be subject to taxation in his hands. The following rules are wel! established by the decisions.

(a) The ordinary one-eighth royalty retained by the lessor is not a part of the income of the lessee or his assignee. ${ }^{33}$

(b) The earnings of a permanent overriding royalty interest are not included in the taxable income of the assignee. ${ }^{34}$

(c) If an oil or gas payment is retained by the assignor out of a fraction of production, the fraction devoted to payment of that sum is not the taxable income of the assignee. ${ }^{35}$

(d) If the assignor reserves an oil payment and in addition a permanent overriding royalty, the fractions devoted to the oil payment and to the override are not the taxable income of the assignee. ${ }^{36}$

(e) However, when the oil payment is gnaranteed by the assignee, or when he has promised to pay the stated amount in any event, irrespective of

after until 1936 it refused to pay over any sums unless and until equal amounts of cash were deposited by Farrell to insure it against liability. The income in question did not become available to the taxpayer or subject to his control and disposition until 1936, and at all times prior thereto the possibility existed that he might never receive it."

See (1940) 53 HaRv. L. Rev. 851, for a very helpful note on the subject, Time When Items Become Income to the Cash Basis Taxpayer."

32 As to installment sales of real property see: Regulations $111, \$ 29.44-1$ and \$29.44-3; 2 Mertens, LAW of Federal Income TAXATION (1942) \& 15.08; (1933) XII-1 CUM. BULI. 52; (1933) XII-2 CuM. BuLL. 57; 1 MONIgOMERY's FederAL TAXES $1944-45,995$.

33 Burnet v. Harmel (1932) 287 U.S. 103.

34 Commissioner v. Fleming (C.C.A. 5th, 1936) 82 F. (2d) 324.

35 Thomas v. Perkins (1937) 301 U.S. 655; Alexander v. Continental Petroleum Company (C.C.A. 10th, 1933) 63 F. (2d) 927.

36 Palmer v. Bender (1933) 287 U.S. 551. 
whether it is earned by production of oil, then the income from the entire seven-eighths leasehold interest is the taxable income of the assignee. ${ }^{37}$

(f) When a stated amount is payable to the assignor out of the net proceeds of the property, then the entire seven-eights leasehold interest is the taxable income of the assignee. ${ }^{38}$

(g) If the assignor has a lien on the fee simple estate to secure payment of the oil payment, then also the entire income from the seven-eights leasehold interest is the taxable income of the assignee. ${ }^{39}$

\section{V. \\ BASIS}

One of the first problems to be considered by the purchaser of a lease is the basis that the property will have.

A.

The basis of the lease depends in part upon the manner of acquisition and in part upon the consideration paid and the manner of payment.

Sometimes the operator deals directly with the landowner and is named in the lease as lessee. Often the operator acquires the lease by assignment from the lessee or an assignee of the lessee.

In most instances a cash bonus is paid and the landowner reserves a royalty of one-eighth. If the lease is already in existence, the operator may pay cash and agree also to pay a fixed amount out of production, or an overriding royalty. The operator may have acquired the lease in exchange for another lease in the same area, or he may have acquired it under an agreement that he will drill on it, or on neighboring lands.

These different methods of acquiring title to a lease raise special problems. The general rule is that the basis of property is the cost of the property. ${ }^{40}$ In most instances the cost of the lease is the basis of the lease; and the problem of fixing the cost is similar to that of fixing the cost of other real estate.

B.

If the operator acquires the lease for cash, the cash paid is the cost of the property.

$3 \pi$ Anderson v. Helvering (1940) 310 U.S. 404.

38 Helvering v. Elbe Oil Land Development Company (1938) 303 U.S. 372; Helvering v. O'Donnell (1938) 303 U.S. 370.

39 Supra note 37.

40 I. R. C. $\S 113$. 
"In the case of the payor, any payment made for the acquisition of an economic interest in a mineral deposit or standing timber constitutes a capital investment in the property recoverable only through the depletion allowance." 41

The royalties which are paid to the landowner are not a part of the cost to the lessee; the royalties are the separate income of the landowner.

Sometimes the landowner will reserve in addition to the royalty a permanent overriding royalty. This override is not a part of the cost of lessee. The override is permanent and the lessee receives not a full seven-eighths interest but a seven-eighths interest reduced by the override. (One thirty-second or one-tenth, or whatever it may be.)

Sometimes the landowner, in addition to retaining the usual oneeighth royalty, retains an additional payment of a stated amount out of one-fourth of seven-eighths. This payment is usually not considered as a part of the assignee's cost of the lease.

However, payments made out of net proceeds are part of the cost of the lease. They are a capital investment and are not to be deducted from the income of the assignee.

In Quintana Petroleum Company v. Commissioner ${ }^{42}$ the following question is presented:

"Was the petitioner, who, as assignee of a producing oil and gas lease, required to develop and operate the lease and to account to the lessee-assignor for one-fourth of the net profits from said lease, entitled to deduct such payments in computing its taxable net income, either as business expenses or as rentals or royalties?"

The answer of the court is as follows:

"Net-profits payments are payments on the purchase price. As capital investments they may not be treated as business expenses or as rentals or as royalties."

In Burton-Sutton Oil Co., Inc., v. Commissioner ${ }^{43}$ we find this statement of the rule:

41 Regulations 111, Section $29.23(\mathrm{~m})-10$ (a). Note the inconsistency. The bonus payment received by the landowner when he executes the lease is ordinary income to him and subject to depletion; but the lessee who pays the bonus is unaking a capital investment.

42 (C.C.A. 5th, 1944) 143 F. (2d) 588.

43 (C.C.A. 5th, 1945) 150 F. (2d) 621. See also Gracey v. Commissioner (1945) 5 T.C. 296, and Innis v. Commissioner (1945) T.C. Mimo Op. Dkts. 2735-6. 
"We need only to reiterate here the principle announced in Quintana Petroleum Co. v. Commissioner of Internal Revenue, 5 Cir., $143 \mathrm{~F} .2 \mathrm{~d} 588$, that a covenant to pay a percentage of net profits from production does not grant an economic interest in oil in place. The payments thereunder were not made with respect to the royalty interests retained by the taxpayer, but were paid as consideration for the execution of the conveyance. The purchase price of a capital asset is not deductible as a business expense, and income is none the less income by reason of its use for investment purposes."

If the landowner or assignor reserves a payment out of oil and gas in a fixed amount and this payment is guaranteed by the lessee, this is a part of the lessee's leasehold cost. These payments also constitute a part of the capital investment and are not to be deducted from the income of the assignee. ${ }^{44}$

If an operating company purchases a lease which has several produring wells for a cash payment and a stated amount out of a fraction of the production, the operator should be concerned with fixing his basis. ${ }^{45}$ If he plans to hold the property and operate it, he should give consideration to fixing his basis for depreciation and depletion. If the property produces oil or gas in substantial quantities, the operator will use percentage depletion and will not be concerned with cost for depletion purposes; he, therefore, should be interested in allocating as much of the consideration as possible to the depreciable equipment. The sales contract sometimes specifies the amount paid for the wells and for the leasehold interest. If the amounts stated are reasonable, they are usually accepted by the Bureau.

When the lease has been acquired in exchange for another lease, the transaction is non-taxable. ${ }^{46}$ The basis will be the basis in the hands of the transferor. ${ }^{4 \pi}$

44 Anderson v. Helvering (1940) 310 U.S. 404 ; Quintana Petroleum Co. v. Commissioner (C.C.A. 5th, 1944) 143 F. (2d) 588.

45 This is the situation in Columbia Oil \& Gas Company v. Commissioner (C.C.A. 5 th, 1941) $118 \mathrm{~F}$. (2d) 459 , although there the immediate problem is to fix the gain of the seller.

463 Mertens, Law of Federal Income Taxatton (1942) § 2023:

"It has been held that the exchange of oil and gas payments due out of oil and gas to be produced from a certaiu lease for the overriding oil and gas royalties of the same lease is not an exchange of properties of like kind where the oil payments were limited in amount and the rigbts of the overriding royalty continued as long as production, and in addition there was a difference in the fractions of the oil and gas which was to be applied currently to the oil and gas payments and to the overriding royalties.

"However, an exchange of an interest in the oil, gas and other minerals in, on, and under land and that might be produced therefrom for an interest in realty improved by 
If the operator acquires the lease in exchange for his promise to drill a well, the assignor will usually retain an override or an oil pay-

a hotel building has been beld to be an exchange of property of like kind, and hence, not recognizable for gain or less purposes."

The cases referred to by Mertens in the above quotation are Midfield Oil Company v. Commissioner and Commissioner v. Crichton. A summary of these cases follows:

In Midfield Oil Company (1939) 39 B.T.A. 1154, the Board of Tax Appeals held that the exchange of an overriding royalty for an oil payment was not an exchange of property of like kind.

"We agree with petitioner that the Holmans oil payment prior to its exchange for the Dawson overriding royalty was held by petitioners for productive use or investment in its trade or business, and we likewise agree that the Dawson royalty was so held by petitioner after it was received in exchange for the Holmans oil payment, but we do not agree that the two properties were of 'like kind' within the meaning of the section of the statute just above quoted.

"There are two differences in the rights created by the Holmans oil payment and the Dawson overriding royalty, both of which we regard as differences of substance and not of mere form. The first difference is that the Holmans oil payment was limited in amount-that is, the right of the holder terminated after a specified amount of proceeds derived from oil and gas produced on the lease had been received by the holder of the oil payment, while the rights of the holder of the Dawson overriding royalty continued for so long as oil or gas might be produced from the leased property.

"The second difference was in the fractions of the oil and gas which were to be applied currently to the oil and gas payment and to the overriding royalty. In the instant case, the fraction of the oil and gas produced on the lease which was to be applied currently to the Holmans oil payment until it was extinguished was four-eights of the entire production of oil and gas from the property. That which was to be paid under the Dawson overriding royalty was five thirty-seconds of seven-eights of the oil and gas until the Holmans oil payment had been paid, and then it became a one-fourth overriding oil and gas royalty, one-fourth of seven-eights.

"While we agree with petitioner that there are some points of similarity between the Holmans oil payment and the Dawson overriding royalty, the differences which we have pointed out are so substantial that we do not think the exchange in question falls within the provisions of section 112 (b) (1). On this point the Commissioner is sustained."

In Commissioner v. Crichton (C.C.A. 5th, 1941) 122 F. (2d) 181, the court holds that an exchange of an interest in an improved city lot for an undivided interest in the oil and gas from an undeveloped tract of land in the country is an exchange of property of like kind and therefore non-taxable.

Circuit Judge Hutcheson stated the facts as follows:

"In 1936, respondent and ber three children, owning, in undivided interests, a tract of unimproved country land and an improved city lot, effected an exchange of interests. Her children transferred to respondent their undivided interest in the city lot. Respondent transferred to her children, as of equal value, an undivided three-twelfths interest in the 'oil, gas and other minerals, in, on and under, and that may be produced from' the country land. The one-half interest conveyed to respondent had a value of $\$ 15,357.77$. The interest respondent transferred to her children had a cost basis of zero."

Circuit Judge Hutcheson states the reason for his decision as follows:

"The commissioner concedes, as he must, that under Louisiana law, mineral rights are interests not in personal but in real property, and that the rights exchanged were real rights. In the light therefore of the rule the regulation lays down, of the examples given in the illustrations it puts forth, and of the construction which, under its interpretation, 
ment. The cost of drilling will be a part of the cost of the lease. Intangible drilling costs will be included in drilling costs if the operator has elected to capitalize them. ${ }^{48}$

When a large tract of land is acquired as a single lease, there usually are certain areas of this tract which are more valuable than others. The cost should be allocated to the various tracts so that each tract bears its correct proportion of cost based on value. ${ }^{40}$ This becomes of extreme importance when parts of the lease are later sold or assigned. The sale of each tract is a separate transaction, and the realization of profit from the sale of separate tracts cannot be postponed until the cost of the entire property has been recovered.

C.

The original cost of the lease is, generally speaking, fixed at the time of acquisition by the consideration paid and the manner of acquisition.

This cost or basis is increased by the drilling of wells and capital expenditures on the property. ${ }^{50}$ As the years go by, the capital investment in the property will change; there will be additions to the

the statue has been given throughout this long period, it will not do for him to now marshal or parade the supposed dissimilarities in grade or quabity, the unlikenesses, in attributes, appearance and capacities, between undivided real interests in a respectively small town hotel, and mineral properties. For the regulation and the interpretation under it, leave in no doubt that no gain or loss is realized by one, other than a dealer, from an exchange of real estate for other real estate, and that the distinction intended and made by the statute is the broad one between classes and characters of properties, for instance, between real and personal property. It was not intended to draw any distinction between parcels of real property however dissimilar they may be in location, in attributes and in capacities for profitable use."

47 I. R. C. $\S 113(a)(6)$.

48 F.H. E. Oil Company v. Commissioner (C.C.A. 5th, 1945) 147 F. (2d) 1002 ; on reh'g (C.C.A.5th, 1945) 149 F. (2d) 238. Second motion for rehearing denied, 150 F. (2d) 854. See article on Intangible Drilling Costs (1943) 21 Tax Mag. 591.

493 Mertens, Law of Federat Income Taxation (1942) \& 21.06.

50 Legal expenses incurred in perfectimg title are part of the cost and are not to be deducted as expenses. Murphy Oil Co. v. Burnet (C.C.A. 9th, 1932) 55 F. (2d) 17, af'd (1932) 287 U.S. 299.

The expense of surveying the land is a part of the cost and should be capitalized. (1924) III-1 CuM. BuLx. 157.

Jones' Estate v. Commissioner (C.C.A.5th, 1942) 127 F. (2d) 231, aff'g 43 B.T.A. 691, holds that expenses incurred in a suit to remove a cloud on title are capital expenditures.

Cost of defending title is a capital cost. Bermont Oil Co. v. Helvering (App. D.C., 1937) 91 F. (2d) 710, af'g (1936) 33 B.T.A. 1061.

The cost of surveys and geological opinions is a capital cost. Seletha $O$. Thompson (1928) 9 B.T.A. 1342. 
property, and part of the investment will be recovered. The general purpose of the adjustments to basis is to provide for a return of capital free of income tax. ${ }^{.1}$

IThenever the operator makes any expenditures in connection with the property, he has to determine whether the expenditure was a capital expenditure or whether it is deductible as an operating expense. Some items which represent capital investments are recoverable through depletion allowances and others through allowances for depreciation.

If the operator, having completed a producing well, decides to sell his lease, his first task will be to fix the basis. He will then make the usual adjustments to capital account to fix the adjusted basis; depreciation which has been taken on equipment and allowances for depletion must be deducted. The difference between the adjusted basis and the selling price will be the taxable gain.

VI.

RECOMMENDATIONS

A

The rules as established by the decisions are obviously difficult to apply. No logical pattern has been evolved, and it is still difficult to predict the course of litigation.

The theory of the existence of an economic interest has been stretched to allow the depletion deduction to taxpayers who are not justly entitled to it. This has distorted the solution of all the related problems.

An end to the litigation could be foreseen if these rules were adopted:

1. The execution of a lease and the assignment of a lease constitute the sale of a capital asset, and the price received shall be treated as income from the sale of a capital asset.

2. The income from the property shall be taxable to the person who holds the legal title.

3. The income from any permanent royalty or overriding royalty interests retained by the lessor or assignor shall be the taxable income of the lessor or assignor.

4. Any limited payments out of a fraction of the working interest shall be treated as the income of the owner of the title to the fractional interest. This rule shall be applied uniformly whether the payment is guaranteed or not, or is out of gross proceeds or net proceeds.

51 See 3 Mertens, Law of Federal, Income Taxation (1942) § 21.161. 
Let us assume that an assignment vests title to the entire leasehold in the purchaser of the lease, but provides that the proceeds from one-fourth of seven-eighths of the oil produced are to be paid to the assignor until he receives $\$ 100,000.00$. The income from the entire seven-eighths should be treated as the taxable income of the assignee for the simple reason that he had title to the entire leasehold.

The contrary rule originated in cases in which the assignor was attempting to secure the benefit of the depletion deduction on the payments made to him by the assignee. The deduction was permitted to the assignor on the theory that he had an economic interest in the land, and the income was held to be his income and not that of the assignee.

The income from property should be taxable to the owner of the property. The holding of title should outweigh any other factors.

B.

There has been a similar roundabout approach to the analysis of problems relating to the basis of a lease, and many of the cases attempt to determine the basis by investigating matters which have no logical relation to basis. If an oil payment is payable out of net proceeds or is a guaranteed oil payment, the opinions state that the income from the fraction devoted to such payments is the taxable income of the assignee; and, therefore, the payments constitute a cost of his interest in the property. This is needless and confusing circumlocution.

To determine the purchase price by considering whose income it is and to determine whose income it is by deciding who receives a deduction is not enlightening.

It should be possible to determine the cost of an article by reference to the purchase agreement. In most sales agreements where there are deferred payments the seller retains title until paid in full. Nevertheless, the payments made are part of the cost of the article purchased.

An assigument of a lease which provides that the seller is to receive a certain sum from a fraction of the working interest is a rather common agreement. The seller has disposed of nost of his interest and retained merely a fraction because he thinks he has improved his position and the fraction will earn more for him than the entire lease was earning prior to the trade. The purchaser plans to develop the lease and earn enough from it to discharge the oil payment. The pur- 
chaser cannot retain the lease and fail to liquidate the oil payment.

No matter whether the seller has or has not an economic interest or has title or does not have title in the fractional interest, the money the purchaser pays him is part of the cost to the purchaser.

As a matter of fact, the deferred payments usually represent a compromise on bonus payments. If the parties cannot agree on the amount of cash to be paid, the payment of a portion in cash and the balance in an oil payment offers an opportunity for agreement.

The oil payment should be a part of the basis of the lease in the assignee's hands no matter whether the title vested in him at the time of the assignment or at the time the payment was liquidated, and no matter whether the payment was a "straight oil payment" or a guaranteed payment, or payable out of gross proceeds or net proceeds. ${ }^{52}$

\section{C.}

An attempt has been made to avoid entanglements with depletion problems. However, it should be noted here that the present rules lead to peculiar results in determining what are separate properties for depletion purposes. The liquidation of an oil payment in a lump sum or over a period of years out of production does not appear to result in the acquisition by the assignee of a separate depletable property.

If the assignor retains title to the fractional interest until the payment is completed, as soon as this occurs, title passes to the assignee and the entire leasehold should be treated as one single depletable property. The basis of the entire leasehold in the hands of the assignee has been increased by the payments made. ${ }^{53}$

However, the regulations require that the fraction devoted to the oil payment be treated as a separate depletable property in the hands of the assignee after the oil payment has been liquidated. ${ }^{5 \cdot 1}$

52 Certainly if title to the entire seven-eighths passes to the assignee at the time of the assignment, the basis should be fixed at that time. Consider the analogous problems arising out of fixing the basis of an estate hy the entirety. Lang v. Commissioner (1933) 289 U.S. 109, and fixing the basis of a contingent remainder, Helvering v. Reynolds (1941) 313 U.S. 428.

To exclude the oil payment from the basis of the assignee in the entire leasehold, and to permit him to deduct it from gross income seems to be contrary to the express prohibition in section 23(a) of the Code which prohibits deduction of payments on property to be used im trade on which the taxpayer has taken title or is taking title, or in which he has an equity. See Citizens National Bank of Kirksville v. Commissioner (C.C.A. 8th, 1941) 122 F. (2d) 1011, cert. den., 315 U.S. 822.

33 Certainly he has not acquired the fractional interest without cost and certainly the whole oil payment is not to be considered the cost of the fractional interest.

541944 CuM. ButI. 250, 253, G.C.M. 24094. 
The theoretical basis of this ruling appears to be that the economic interest of the assignor in the fraction has now passed to the assignee.

If the title to the entire leasehold passes at the time of the assignment, the income from the entire leasehold should be the income of the owner of the leasehold, and the oil payments should be included in his basis; the entire leasehold should be treated as a single property for depletion purposes. 